\title{
EXTRACTIVE SPECTROPHOTOMETRIC METHODS FOR DETERMINATION OF RASAGILINE MESYLATE IN PHARMACEUTICAL FORMULATIONS USING ACIDIC TRIPHENYLMETHANE DYES
}

\author{
CHENNAIAH $M^{2}$, VEERAIAH T ${ }^{* 1}$, CHARAN SINGH T AND VENKATESHWARLU $G^{2}$ \\ ${ }^{2}$ Department of Chemistry, Nizam College (O.U.), Hyderabad, 500001, India \\ ${ }^{1}$ Department of Chemistry, SAP College Vikarabad, Ranga Reddy, Andhra Pradesh, 501101, India
}

(Received: April 19, 2011 - Accepted: October 13, 2011)

\begin{abstract}
Three simple and sensitive extractive spectrophotometric methods have been described for the assay of Rasagiline mesylate either in pure form or in pharmaceutical formulations. The developed methods involve formation of coloured chloroform extractable ion-pair complexes of the drug with bromothymol blue (BTB), bromophenol blue (BPB) and bromocresol green (BCG) in acidic medium. The extracted complexes showed absorbance maxima at 414 nm for all three methods. Beer's law is obeyed in the concentration ranges 3.0-30, 3.0.0-30 and $2.0-25 \mu \mathrm{g} / \mathrm{ml}$ with BTB, BPB and BCG respectively. The effect of concentration of dye, $\mathrm{pH}$, and interference of excipients have been studied and optimized. The limits of detection and quantification have been determined for three methods. All the three methods have been validated as per the guidelines of ICH. The methods have been applied to the determination of drug in commercial tablets and results of analysis were validated statistically through recovery studies.
\end{abstract}

Key-words: Rasagiline mesylate; Bromothymol blue; Bromophenol blue; Bromocresol green; Spectrophotometry

\section{INTRODUCTION}

Rasagiline mesylate is a chemical inhibitor of the enzyme monoamine oxidase type-B which has a major role in the inactivation of biogenic and dietderived amines in the central nervous system ${ }^{1}$. Rasagiline is a propargylaminebased drug indicated for the treatment of idiopathic Parkinson's disease ${ }^{2}$. It is designated chemically as: 1H-Inden-1-amine, 2, 3-dihydro-N-2-propynyl-, (1R)-, methanesulfonate. Literature survey reveals that a Gas ChromatographyMass Spectrometry(GCMS) method for quantification of the drug has been developed by J.J. Thebault etal ${ }^{3}$. The LC-MS/MS method for assay of the drug in human plasma and its application to a pharmacokinetic study has been reported by X. Chen $e^{2} l^{4}$. A similar method has been published for estimation of drug in pharmaceuticals as well as biological fluids like urine and plasma by M. Song etal ${ }^{5}$. Isocratic stability indicating Liquid Chromatographic methods have also been developed for assay of drug ${ }^{6,7}$. All the methods mentioned above either involve costly equipment or tedious experimentation for the analysis of the drug. Simple Spectrophotometric methods are very scarce and we find one direct UV Spectrophotometric method ${ }^{8}$ and one method based on development of colour by Folin-Ciocalteau reagent ${ }^{9}$ in the literature.

Although extractive spectrophotometric methods are simple, sensitive and accurate, surprisingly have not been used for quantification of Rasagiline mesylate. It is therefore thought development of methods of quantification based on extractive spectrophotometry is important and necessary. In this paper we report three extractive spectrophotometric methods based on ionpair complexation of drug with acidic dyes viz., bromothymol blue (BTB), bromophenol blue (BPB) and bromocresol green (BCG).

\section{MATERIALS AND METHODS}

Rasagiline mesylate is procured from Symed labs limited, Hyderabad as a gift sample. The dyestuffs viz., BTB, BPB and BCG (AR grade) supplied by SD Fine Chemicals Ltd. Mumbai, are used without any further purification. The dyestuffs were used as $0.025 \%$ solutions in doubly distilled water. Sodium acetate-hydrochloric acid buffers ${ }^{10}$ of $\mathrm{pH} 2.5,2.8$ and 3.5 were prepared by mixing $50 \mathrm{ml}$ of $1.0 \mathrm{M}$ sodium acetate solution with $50.50,49.50$ or $46.25 \mathrm{ml}$ respectively, of $1.0 \mathrm{M} \mathrm{HCl}$ solution and diluted to $250 \mathrm{ml}$ with doubly distilled water. The $\mathrm{pH}$ of each solution was adjusted to an appropriate value with the aid of a $\mathrm{pH}$ meter. Chlorofom (HPLC grade) supplied by SD Fine Chemicals Ltd. Mumbai is used throughout the work. Stock solutions were prepared for all the dyes and drugs $(25 \mathrm{mg} / 100 \mathrm{ml})$.

The spectra (Fig.1) of ion-pair complexes have been recorded on SHIMADZU 140 double beam spectrophotometer, Thermo Nicolet 1000 and also on ELICO 159 UV-Visible single beam spectrophotometer using quartz cells of $10 \mathrm{~mm}$ path length. An Elico model Li-120 pH meter was used for $\mathrm{pH}$ measurement.

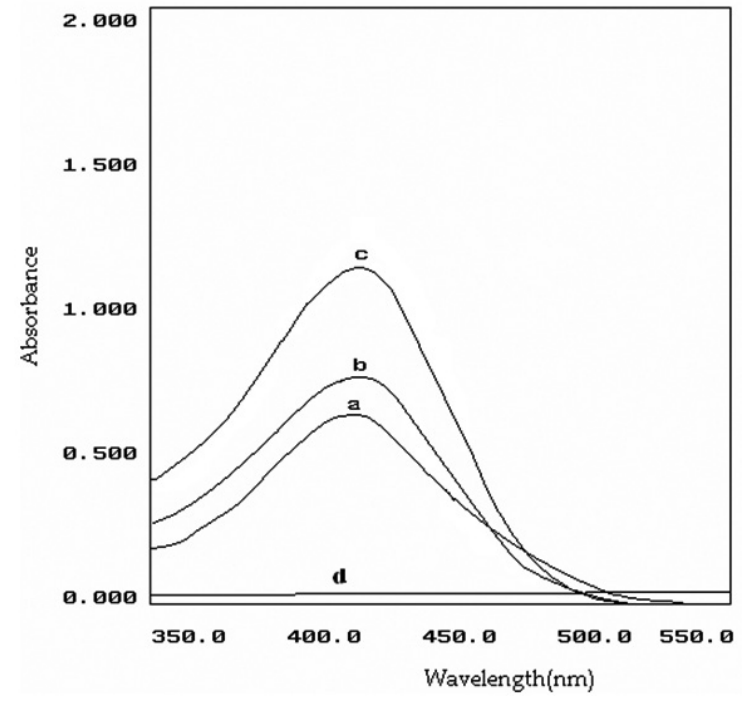

Fig. 1 Absorption spectra of Rasagiline mesylate-dye complex extracted into $10 \mathrm{ml}$ chloroform: (a) drug $=25 \mathrm{mg} \mathrm{ml}^{-1}+5 \mathrm{ml}$ of $0.025 \% \mathrm{BTB}+5 \mathrm{ml}$ of $\mathrm{pH} 2.8$ buffer; (b) drug $=25 \mathrm{mg} \mathrm{ml}^{-1}+5 \mathrm{ml}$ of $0.025 \% \mathrm{BPB}+5 \mathrm{ml}$ of $\mathrm{pH} 2.5$ buffer; (c) drug $=22.5 \mathrm{mg} \mathrm{ml}^{-1}+5 \mathrm{ml}$ of $0.025 \% \mathrm{BCG}+5 \mathrm{ml}$ of pH 3.5 buffer; (d) Drug $=0 \mathrm{mg} \mathrm{ml}{ }^{-1}+5 \mathrm{ml}$ of $0.025 \%$ Dye $+5 \mathrm{ml}$ of buffer.

\section{RESULTS AND DISCUSSION}

Rasagiline mesylate forms ion-pair complexes in acidic buffer with dyestuffs such as bromothymol blue (BTB), bromophenol blue (BPB) and bromocresol green $(\mathrm{BCG})$ and these complexes are quantitatively extracted into chloroform. Ion-pair complexes of drug with BTB, BPB and BCG absorbed maximally at $414 \mathrm{~nm}$. The reagent blank under similar conditions showed no absorption.

Rasagiline mesylate contains only one secondary amino group which is protonated in acid medium, while sulphonic acid group is present in BTB, BPB and $\mathrm{BCG}$, that is the only group undergoing dissociation in the $\mathrm{pH}$ range 1-5. The colour of such dyes is due to the opening of lactoid ring and subsequent formation of quinoid group. It is supposed that the two tautomers are present in equilibrium but due to strong acidic nature of the sulphonic acid group, the quinoid body must predominate. Finally the protonated Rasagiline mesylate forms ion-pairs with the dyestuffs which are quantitatively extracted into chloroform. The possible reaction mechanisms are proposed and given in (Scheme 1). 

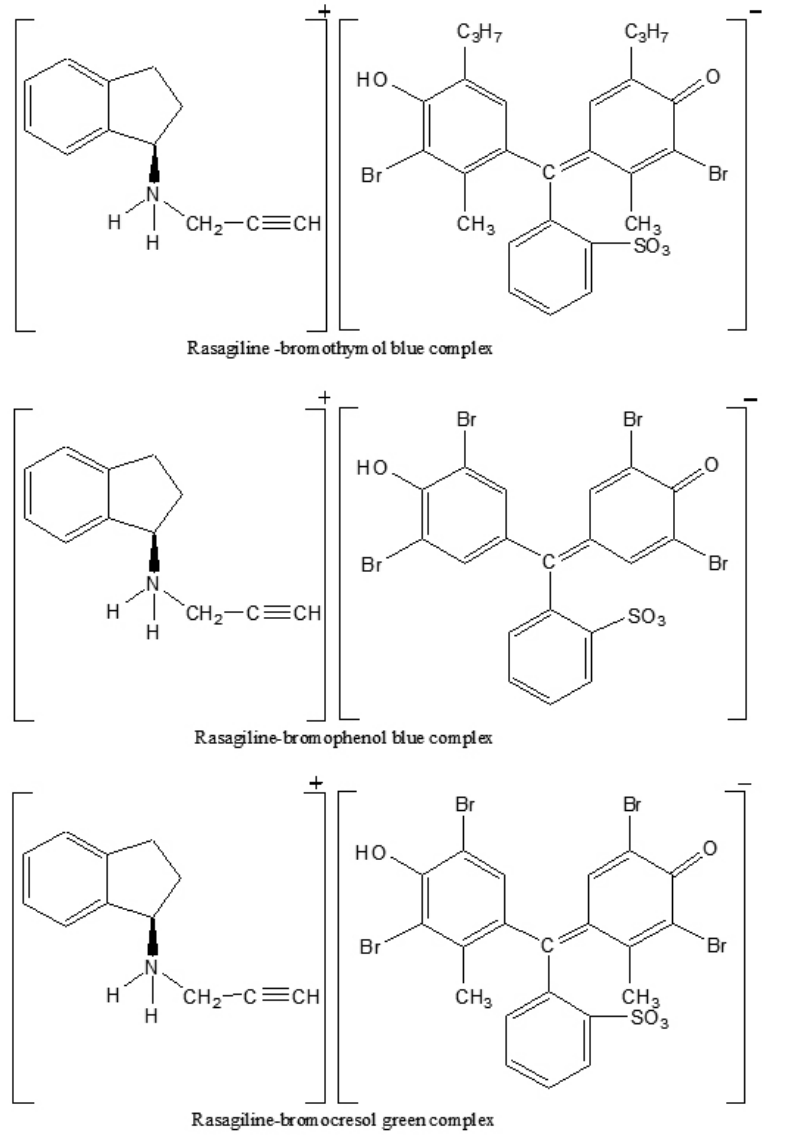

Scheme 1

Calibration curve

Different aliquots of drug solution were transferred into $125 \mathrm{ml}$ separating funnel. To this $5 \mathrm{ml}$ of buffer ( $\mathrm{pH} 2.5,2.8$ and 3.5), $5 \mathrm{ml}$ of dye were added and total volume was made up to $20 \mathrm{ml}$ with water. $10 \mathrm{ml}$ of chloroform was added and the contents were shaken for $5 \mathrm{~min}$. The two layers were allowed to separate for $5 \mathrm{~min}$. The organic layer was separated and absorbance of yellow colored solution which is stable atleast for $3 \mathrm{hrs}$ is measured at $414 \mathrm{~nm}$ against blank similarly prepared. The same procedure of analysis is followed either for assay of pure drug or for dosage form. The calibration graphs (Fig. 2) are linear over the concentration ranges are within the permissible range. The optical characteristics and statistical data for the regression equation of the proposed methods are presented in (Table 1).

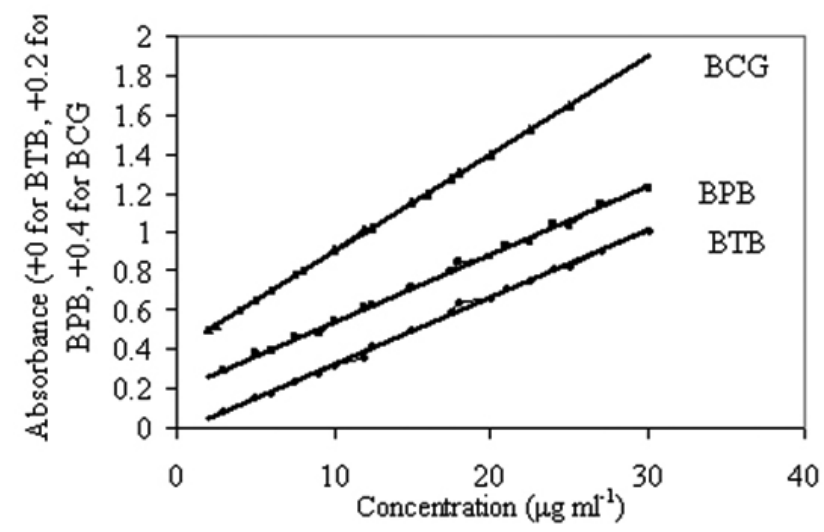

Fig. 2: Calibration graphs for Drug-BTB, BPB \& BCG ion pair complexes.
Table 1 Optical characteristics and statistical for the regression equation of the proposed methods.

\begin{tabular}{lccc}
\hline & \multicolumn{3}{c}{ Extraction methods with } \\
\cline { 2 - 4 } Parameters & BTB & BPB & BCG \\
\cline { 2 - 4 } & & & \\
$\lambda_{\max }(\mathrm{nm})$ & 414 & 414 & 414 \\
Beer's law limit $\left(\mu \mathrm{g} \mathrm{ml}^{-1}\right)$ & $3.0-30$ & $3.0-30$ & $2.0-25$ \\
Molar absorptivity $\left(\mathrm{L} \mathrm{mol}^{-1} \mathrm{~cm}^{-1}\right)$ & 8072 & 8242 & 13557 \\
Formation constant, $\mathrm{K}, ~^{-1}$ & $1.37 \times 10^{6}$ & $1.28 \times 10^{6}$ & $1.7 \times 10^{6}$ \\
Sandell sensitivity $\left(\mu \mathrm{g} \mathrm{cm}^{-2}\right)$ & 0.0292 & 0.0287 & 0.02 \\
Slope $($ specific absorptivity), b & 0.0342 & 0.0347 & 0.0498 \\
Intercept (a) & -0.0153 & -0.0088 & 0.0065 \\
Correlation coefficient $(\mathrm{r})$ & 0.9986 & 0.9985 & 0.9999 \\
Standard deviation of intercepts $(\% \mathrm{n}=6)$ & 0.0042 & 0.007 & 0.0029 \\
Limit of detection, $\mu \mathrm{gml}{ }^{-1}$ & 0.4054 & 0.6647 & 0.1932 \\
Limit of quantification, $\mu \mathrm{gmml}{ }^{-1}$ & 1.23 & 1.9942 & 0.5797 \\
Regression equation & $\mathrm{Y}=0.0342 \mathrm{C}-$ & $\mathrm{Y}=0.0347 \mathrm{C}-$ & $\mathrm{Y}=0.0498 \mathrm{C}+$ \\
& 0.0153 & 0.0088 & 0.0065
\end{tabular}

${ }^{a}$ With respect to $Y=b c+a$, where $\mathrm{C}$ is the concentration $\left(\mu \mathrm{g} \mathrm{ml}^{-1}\right)$ and $Y$ is absorbance ${ }^{\mathrm{b}}$ Six replicate samples.

Procedure for the assay of pure drug

Five different solutions of pure drug in the range of calibration curve were selected and the recovery experiments were performed. The recoveries and their relative standard deviations are tabulated in (Table 2).

Table 2: Application of proposed methods for the analysis of rasagiline mesylate in pure form.

\begin{tabular}{|c|c|c|c|c|c|c|c|}
\hline \multirow{3}{*}{$\begin{array}{l}\text { Taken } \\
\left(\mu \mathrm{g} \mathrm{ml}^{-1}\right)\end{array}$} & \multicolumn{5}{|c|}{ Proposed methods } & \multicolumn{2}{|c|}{ Reference method [7] } \\
\hline & \multicolumn{3}{|c|}{$\begin{array}{c}\text { Found } \\
\left(\mu \mathrm{g} \mathrm{ml}^{-1}\right)\end{array}$} & \multicolumn{3}{|c|}{ Recovery (\%) } & \multirow[t]{2}{*}{ Recovery (\%) } \\
\hline & BTB & BPB & BCG & $\overline{\mathrm{BTB}}$ & BPB & $\overline{\mathrm{BCG}}$ & \\
\hline 6 & 6.04 & 6.04 & 6.11 & 100.63 & 100.65 & 101.86 & 100.3 \\
\hline 10 & 10.13 & 10.19 & 9.97 & 101.35 & 101.86 & 99.7 & 100.2 \\
\hline 14 & 14.05 & 14.13 & 14.01 & 100.35 & 100.90 & 100.04 & 100.8 \\
\hline 18 & 17.97 & 18.07 & 18.04 & 99.82 & 100.37 & 100.23 & 100.3 \\
\hline \multirow[t]{2}{*}{22} & 22.33 & 21.95 & 22.11 & 101.51 & 99.77 & 100.89 & 100.5 \\
\hline & & & & & & & 99.7 \\
\hline $\operatorname{RSD}(\%)$ & & & & 0.6972 & 0.761 & 0.8514 & 0.6125 \\
\hline Mean \pm SD & & & & $100.7 \pm 0.7$ & $100.7 \pm 0.76$ & $100.54 \pm 0.86$ & $100.46 \pm 0.61$ \\
\hline t-test & & & & 0.659 & 0.5768 & 0.179 & \\
\hline F-test & & & & 1.3 & 1.55 & 1.936 & \\
\hline
\end{tabular}

\section{Procedure for the assay of dosage forms}

Ten tablets of Azilect $1 \mathrm{mg}$ are powdered and dissolved in doubly distilled water and stirred thoroughly, filtered through a Whatman No. 42 filter paper. This solution was transferred into $100 \mathrm{ml}$ standard volumetric flask and diluted with doubly distilled water as required. Different solutions of drug in the range of calibration curve were chosen and the assay was estimated using the calibration curve. The results of the recovery experiments are tabulated in (Table 3). 
Table 3: Application of proposed methods for the analysis of rasagiline mesylate in pharmaceuticals form.

\begin{tabular}{|c|c|c|c|c|c|c|c|}
\hline \multirow{3}{*}{$\begin{array}{l}\text { Taken } \\
\left(\mu \mathrm{g} \mathrm{ml}^{-1}\right) \\
\text { Azilect } 1 \mathrm{mg} \\
\text { Tablet }\end{array}$} & \multicolumn{4}{|c|}{ Proposed methods } & \multicolumn{3}{|c|}{ Reference method [7] } \\
\hline & \multicolumn{3}{|c|}{$\begin{array}{l}\text { Found } \\
\left(\mu \mathrm{g} \mathrm{ml}^{-1}\right)\end{array}$} & \multicolumn{3}{|c|}{ Recovery (\%) } & Recovery (\%) \\
\hline & BTB & BPB & $\overline{B C G}$ & $\overline{\text { BTB }}$ & BPB & $\overline{\mathrm{BCG}}$ & \\
\hline 4.5 & 4.58 & 4.51 & 4.48 & 101.8 & 100.27 & 99.73 & 100.3 \\
\hline 9 & 9.11 & 9.0 & 9.02 & 101.23 & 100.03 & 100.28 & 100.2 \\
\hline 13.5 & 13.52 & 13.72 & 13.6 & 100.17 & 101.67 & 100.76 & 100.8 \\
\hline 18 & 18.02 & 17.97 & 18.03 & 100.15 & 99.88 & 100.19 & 100.3 \\
\hline \multirow[t]{2}{*}{22.5} & 22.47 & 22.53 & 22.46 & 99.88 & 100.12 & 99.82 & 100.5 \\
\hline & & & & & & & 99.7 \\
\hline RSD (\%) & & & & 0.8216 & 0.7231 & 0.4101 & 0.6125 \\
\hline Mean \pm SD & & & & $100.64 \pm 0.83$ & $100.39 \pm 0.73$ & $100.16 \pm 0.41$ & $1 \quad 100.46 \pm 0.6$ \\
\hline t-test & & & & 0.4083 & 0.166 & 0.9774 & \\
\hline F-test & & & & 1.8059 & 1.1319 & 0.4456 & \\
\hline
\end{tabular}

In order to establish molar ratio between Rasagiline mesylate and dyestuffs used, the Job's method of continuous variation ${ }^{11}$ has been applied. In this method, solutions of drug and dyestuff with identical molar concentrations (8 x $10^{-5} M$ ) were mixed in varying volume ratios in such a way that the total volume of each mixture was the same. The absorbance of each solution was measured and plotted against the mole fraction of the drug, [drug]/ [drug] + [dyestuff] (Fig. 3). This measurement showed that 1:1 complex was formed with each dyestuff. The formation constants ${ }^{12,13}$ were also estimated and found to be $1.37 \times 10^{6}, 1.28 \times 10^{6}$ and $1.7 \times 10^{6} \mathrm{~K} \mathrm{M}^{-1}$ for complexes with BTB, BPB and $\mathrm{BCG}$ respectively.

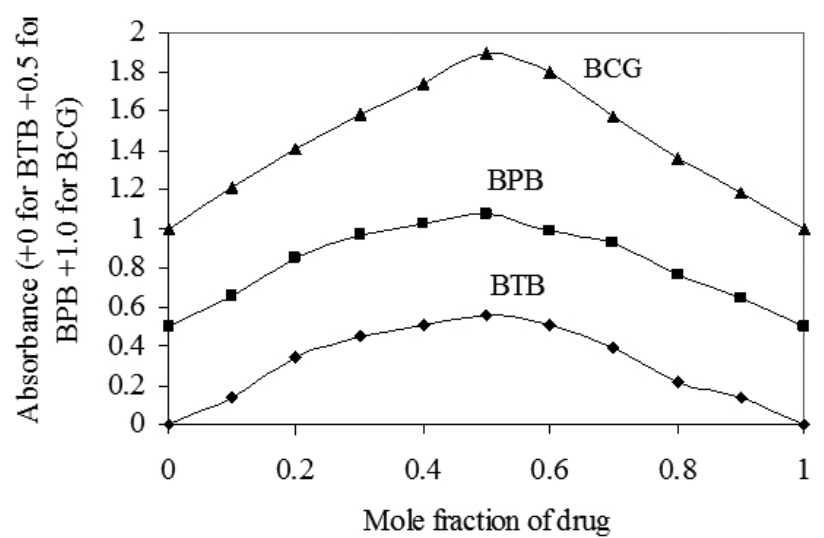

Fig. 3: Continuous-variations study of drug-dye systems: $[$ Drug $]=[$ Dye $]$ $=8 \times 10^{-5} \mathrm{M}$

The influence of $\mathrm{pH}$ on the ion-pair formation of Rasagiline mesylate with various dyestuffs has been studied using sodium acetate-hydrochloric acid buffer. The results are shown in (Fig. 4). It is evident that absorbance of complexes with BTB, BPB and BCG was found to be constant within the $\mathrm{pH}$ ranges $2.2-3.3,2.0-3.0$ and $2.8-3.8$ respectively. Thus, all the absorbance measurements were made at $\mathrm{pH} 2.8,2.5$ and 3.5 with BTB, BPB and BCG respectively.

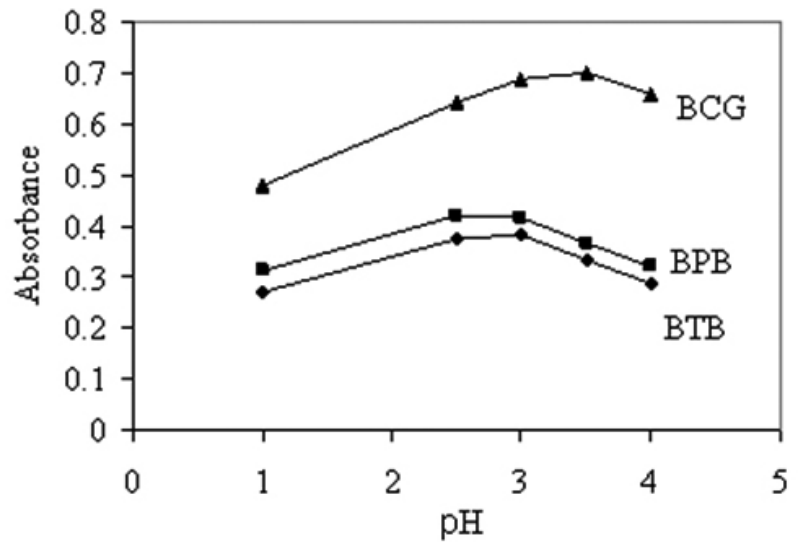

Fig. 4: Effect of $\mathrm{pH}[\mathrm{Drug}]=\left[15 \mu \mathrm{g} \mathrm{ml}^{-1}\right.$, $[$ Dye $]=5 \mathrm{ml}$ of $0.025 \%$

The effect of dyestuff concentrations was also studied by adding different volumes of dyestuff to a constant amount of Rasagiline mesylate $\left(15 \mu \mathrm{g} \mathrm{ml}^{-1}\right)$. It is apparent from (Fig. 5). That the maximum absorbance, in each case, was found with $3.0 \mathrm{ml}$ of dyestuff, beyond which absorbance was constant. Thus, 5 $\mathrm{ml}$ of each dyestuff was used for ion-pair formation throughout the experiment.

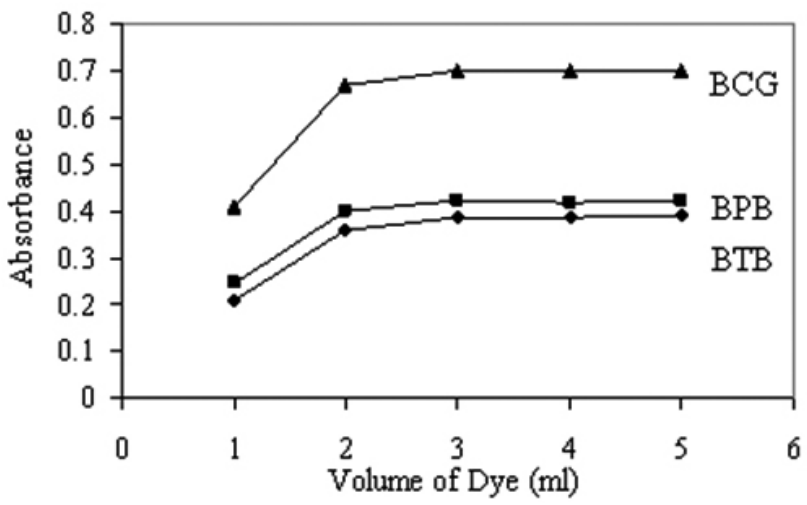

Fig 5: Influence of the volume of $0.025 \%$ Dye, $[$ Drug $]=15 \mu \mathrm{g} \mathrm{ml}^{-1}$

A systematic study of the effect of foreign species present along with Rasagiline mesylate on the determination of Rasagiline mesylate at $10 \mu \mathrm{g} \mathrm{ml}^{-1}$ levels was undertaken. This study was carried out by following the proposed procedures for a $10 \mathrm{ml}$ sample system, by adding a known amount of foreign species to a Rasagiline mesylate solution of $10 \mu \mathrm{g} \mathrm{ml}^{-1}$ (Table 4) summarizes the results obtained. However, the drug content from the powdered tablets was extracted into chloroform, which completely removes any interference by the common excipients found in formulations.

Table 4: Interference study.
S. No.
Excipients
Tolerance limit
$\left(\mu \mathrm{g} \mathrm{ml}^{-1}\right)$

$\begin{array}{llr}\text { 1. } & \text { Microcrystalline cellulose } & 80 \\ \text { 2. } & \text { Starch } & 170 \\ \text { 3. } & \text { Lactose } & 125 \\ \text { 4. } & \text { Magnesium stearate Colloidal } & 90 \\ \text { 5. } & \text { Silicon dioxide } & 75 \\ \text { 6. } & \text { Titanium dioxide } & 20\end{array}$


Validation of the proposed method

All the three proposed methods have been validated in terms of guideline proposed by $\mathrm{ICH}^{14}$ viz. selectivity, specificity, accuracy, precision, limits of calibration curve, LOD, LOQ, robustness, ruggedness and regression equation. The student $\mathrm{t}$-test and variance $\mathrm{F}$-test have been performed in comparison with a reference method. (Table1) summarizes the values for Beer's law limits, molar absorptivity, regression equation, correlation coefficients, relative standard deviation and recoveries. To test the reproducibility of the proposed methods, six replicate determinations of $15 \mu \mathrm{g} \mathrm{ml}^{-1}$ of Rasagiline mesylate were made. The coefficient of variation was found to be less than $1.2 \%$ for all the procedures.

The proposed methods have been successfully applied to the determination of Rasagiline mesylate in pharmaceutical preparations. The performance order of the proposed methods is $\mathrm{BCG}>\mathrm{BPB}>\mathrm{BTB}$. The results obtained and shown in (Table 2 and Table 3) were compared to those obtained by a reference method $^{7}$ by means of $t$-test at $95 \%$ confidence level. In all cases, the average results obtained by proposed methods and reference method were statistically identical, as the difference between the average values had no significance at $95 \%$ confidence level.

The proposed methods are simple, sensitive and reproducible and can be used for routine analysis of Rasagiline mesylate in pure form and in formulation.

\section{CONCLUSIONS}

Rasagiline mesylate forms ion pair complexes with acidic triphenylmethane dyes having 1:1 composition and are extractable into chloroform and formed a basis for assay of the drug. The method is validated and applied to pharmaceuticals. The methodologies developed are useful either in bulk drug or in pharmaceutical industries. The extraction of drug is optimum at a $\mathrm{pH}$ of 2.8. 2.5 and 3.5 for BTB, BPB and BCG respectively. The optimum absorbance is observed when $5 \mathrm{ml}$. of $0.025 \%$ dye is used. The excipients present in the tablet matrix do not interfere in the process of determination of drug using these dyes. The performance order of the proposed methods is $\mathrm{BCG}>\mathrm{BPB}$ $>$ BTB.

\section{ACKNOWLEDGEMENTS}

The authors are grateful to the Head of the Department Chemistry and the Principal, Nizam College for providing facilities. MC is thankful to UGC for FDP fellowship. TV is thankful to Sri M. Ravindra Reddy, Chairman, Managing Committee SAP College, Vikarabad for providing facilities and to the UGC for financial assistance under Major Research Project.

\section{REFERENCES}

1. M.B. Youdim, W. Maruyama, M. Naoi, Drugs Today, 41(6), 369, (2005).

2. J. J. Chen, M.D. Swope, K. Dashtipour, Clin. Therap. 29, 1825, (2007).

3. J.J.Thebault, M. Guillaum, R. Levy, Pharmacotherap. 24, 1295, (2004).

4. X. Chen, X. Duan, J. Ma, P. Deng, H. Wang, D. Zhong, J. Chromatograph. B. 873, 203, (2008)

5. M.Song, L. Wang, H. Zhao, T. Hang, A. Wen, L. Yang, L. Gia, J. Chromatograph. B. 875, 515, (2008).

6. M. Fernandez, E. Barica, S. Negro, J. Pharm. Bio-Med. Anal. 49, 1185, (2009).

7. R. Narendra Kumar, G. Nageswara Rao, P.Y. Naidu, Inter. J. Bio. Pharm. Tech. 1, 247, (2010).

8. B. Rama, K. Preeti, Inter. J. Pharm. Sci. Rev. Res. 5, 05, (2010).

9. G. Devala Rao, S. Kathirvel, S. V. Satyanarayana, J. Pharm. Res. 4, 61, (2011).

10. H.T.S. Britton, Hydrogen Ions, Chapman and Hall, London, Vol. 1, 1942.

11. W.C. Vosburgh, G. R. Coopper, J Am Chem Soc. 63, 437, (1941).

12. W. Likussar, D.F. Boltz, Anal Chem. 43, 1265, (1971).

13. K. Momoki, J. Sekino, H. Sato, N. Yamaguchi, Anal Chem. 41, 1286 , (1969).

14. International Conference on Harmonization (ICH) of Technical Requirement for the Registration of Pharmaceuticals for Human use, Validation of analytical procedures: definitions and Terminology Genera, (1996). 